\title{
Penisilin Grubu Antibiyotiklerin Ayrımı ve Penisilin V'nin Farmasötik ve İdrar Numunelerinde Analizi İçin Miseller Sıvı Kromatografi Yönteminin Geliştirilmesi ve Validasyonu
}

\author{
Gizem Y1ldırım Baştemur ${ }^{1 *}$ \\ ${ }^{1}$ İstanbul Üniversitesi, Fen Bilimleri Enstitüsü, Moleküler Biyoloji ve Genetik Bölümü, İstanbul, Türkiye (ORCID: 0000-0002-4634-4525)
}

(İlk Geliş Tarihi 3 Ekim 2019 ve Kabul Tarihi 8 Kasım 2019)

(DOI: 10.31590/ejosat.628749)

ATIF/REFERENCE: Yıldırım Baştemur, G. (2019). Penisilin Grubu Antibiyotiklerin Ayrımı ve Penisilin V'nin Farmasötik ve İdrar Numunelerinde Analizi İçin Miseller Sıvı Kromatografi Yönteminin Geliştirilmesi ve Validasyonu. Avrupa Bilim ve Teknoloji Dergisi, (17), 703-710.

$\ddot{\mathbf{O} z}$

Penisilin grubu antibiyotikler, yan etkilerinin azlığı ve bakterisid olmaları nedeniyle günümüzde en sık kullanılan antibiyotik grubudur. $\mathrm{Bu}$ ilaçların olumlu etkilerine rağmen tüketiminden sonra yiyecek veya sulu ortamlarda bulunması ciddi sağlı sorunlarına yol açmaktadır. Ayrıca hayvan yemindeki penisilin kalıntılarının varlığı, insanların et ve süt ürünlerini tüketmesi ile ağır alerjik tepki gibi halk sağ lı̆̆ üzerinde olumsuz etkiler yaratabilmektedir. Bu nedenle bu bileşiklerin tayinleri için analitik metotlarda bir gelişme veya bu bileşiklerin özellikleri ile ilgili bir bilgi büyük katkı sağlayacaktır. İlaç formunda yer alan (tablet, kapsül vb.) etken maddenin tanımlanmasında, klinik çalışmalar sırasında plazma ve serum gibi fizyolojik sıvılardaki ilaç ve olası metabolitlerin tayini için HPLC yöntemi kullanılmaktadır. Bu çalışmada penisilin grubu 4 bileşiğin (metisilin, penisilin $\mathrm{V}$, amoksasilin, ampisilin) ayrımı ve farmasötik ve idrar numunelerinden Penisilin V'nin kantitatif tayini için miseller sıvı kromatografi (MLC) metodu geliştirilmiş ve valide edilmiştir. Analizler X-Terra RP18 (250 mm x 4,6 mm I.D., $5 \mu \mathrm{m})$ kolununda gerçekleştirilmiştir. Hareketli faz olarak 1- bütanol-su (\% 5 (h/h)) ortamında $0,05 \mathrm{M}$ sodyum dodesil sülfat içeren 0,01 fosfat ( $\mathrm{pH} 3,5)$ tamponu kullanılmıştır. Akış hızı 1,3 mL dk ${ }^{-1}$, enjeksiyon hacmi 20 $\mu \mathrm{L}$, kolon sıcaklığ $30{ }^{\circ} \mathrm{C}$, dedeksiyon dalga boyu $200 \mathrm{~nm}$ 'dir. Geliştirilen metot için sistem uygunluk parametreleri çalışılmış ve kabul edilebilir sonuçlar elde edilmiştir. Doğrusallık, seçicilik, dedeksiyon limiti (LOD), kantitatif tayin limiti (LOQ), gün içi ve günler arası kesinlik parametreleri belirlenerek metot validasyonu gerçekleştirilmiştir. Penisilin V için kalibrasyon eğrisi 2-20 mg/L konsantrasyon aralığında doğrusaldır $\left(\mathrm{R}^{2}=0,9998\right)$ ve LOD ve LOQ sırasıyla $0,203 \mathrm{mg} / \mathrm{L}$ ve $0,679 \mathrm{mg} / \mathrm{L}$ olarak bulunmuştur. Bu metot çeşitli farmasötik formülasyonlar ve insan idrar numunelerinde penisilin $\mathrm{V}$ tayinine uygulanmıştır.

Anahtar Kelimeler: Miseller sıvı kromatografi, Beta-laktam antibiyotikler, Penisilin V, Metot validasyonu

\section{Development and Validation of Micellar Liquid Chromatography Method for Separation of Penicillin Group Antibiotics and Analysis of Penicillin V in Pharmaceutical and Urine Samples}

\begin{abstract}
Penicillin group antibiotics are the most commonly used antibiotics group due to the have less side effects and bactericide. Despite the positive effects of these drugs, the presence of food or aqueous media after consumption leads to serious health problems. Furthermore, in the presence of penicillin residues in animal feed, due to the consumption of meat and dairy products may have a negative impact on public health such as severe allergic reaction. Therefore, an improvement in analytic methods for determination of such compounds or an information about the characteristics of these compounds, will make great contributions. HPLC methods is used for idendification of the active substance in the form of pharmaceutical (tablets, capsules, etc.) and to determine the drug and possible metabolites in
\end{abstract}

* Gizem Yıldırım Baştemur: İstanbul Üniversitesi, Fen Bilimleri Enstitüsü, Moleküler Biyoloji ve Genetik Bölümü, İstanbul, Türkiye (ORCID: 00000002-4634-4525), gyildirimbastemur@gmail.com 
plasma and serum physiological fluids during clinical trials. In this study, micellar liquid chromatography (MLC) method has been developed and validated for the separation of the penicillin group 4 compounds (methicillin, penicillin V, amoxacillin, ampicillin) and quantitative determination of penicillin V from pharmaceutical and urine samples. Analyzes were performed on the X-Terra RP18 (250 $\mathrm{mm} \times \mathrm{m}$ 4,6 mm I.D., $5 \mu \mathrm{m}$ ) column. The mobile phase is 0.01 phosphate ( $\mathrm{pH} \mathrm{3.5)} \mathrm{buffer} \mathrm{containing} 0.05 \mathrm{M}$ sodium dodecylsulfate in 5 $\%(\mathrm{v} / \mathrm{v}) 1$-butanol-water. Flow rate is $1.3 \mathrm{~mL} \mathrm{~min}^{-1}$, injection volume is $20 \mu \mathrm{L}$, column temperature is $30{ }^{\circ} \mathrm{C}$, detection wavelength is $200 \mathrm{~nm}$. For the developed method, system suitability parameters were studied and acceptable results were obtained. Method was validated by the determination of linearity, selectivity, limit of detection (LOD), limit of quantification (LOQ), intra-day and inter-day precision parameters. The calibration curve for penicillin $\mathrm{V}$ is linear in the concentration range of 2-20 mg/L. LOD and LOQ were found to be $0.203 \mathrm{mg} / \mathrm{L}$ and $0.679 \mathrm{mg} / \mathrm{L}$, respectively. This method has been applied to the determination of penicillin $\mathrm{V}$ in various pharmaceutical formulations and human urine samples.

\section{Keywords: Micellar liquid chromatography, Beta lactam antibiotics, Penicillin V, Method validation}

\section{Giriş}

Antibiyotikler, mikroorganizmalar tarafından üretilen ya da yok edilen (bakterisid) veya diğer mikroorganizmaların (bakteriyostatik) büyümesini engelleyen kimyasal maddelerdir. Bütün bakterilerde yavaş gelişme, hızlı gelişme ve dinlenme dönemlerinden oluşan üç çoğalma evresi vardır ve antibiyotikler bakterilerin hızlı ve yavaş gelişme dönemlerinde etki göstermektedirler (Schugerl, 2001). Antibiyotikler ya çok çeşitli mikroorganizmalara karşı aktif olan geniş spektrumlu ya da belirli bir organizma grubuna karşı aktif olan dar spektrumlu olabilir. Genel olarak antibiyotikler i) bakteri hücre çeperi bileşenlerinin sentezinin önlenmesi; ii) bakteriyel sitoplazmik membrana zarar vermek; iii) protein veya nükleik asit sentezine müdahale ederek çalışmaktadır (Samanidou ve Evaggelopoulou, 2007).

Penisilinler, antibiyotiklerin en önemli gruplarından birini oluştururlar. İlk penisilinin kullanıma girmesinden sonra başka antimikrobik ajan üretilmiş olmasına rağmen penisilinler hala çok geniş kullanıma sahiptir ve penisilinin yeni türevleri üretilmeye devam etmektedir. Penisilin ve türevlerinin temel yapısı 6-aminopenisilanik asit (6-APA) çekirdeğidir ve bu çekirdek, bir tiazolidin halkasıyla ona bir yan zincirle bağlanan beta laktam halkasından oluşur. Biyolojik aktivite için 6-APA çekirdeğinin bütünlüğünü koruması gereklidir. Beta laktam halkasına bağlı sekonder amin grubuna çeşitli radikaller bağlanarak amid bağını oluştururlar. Bu şekilde farmakokinetik ve farmakolojik farkl1lıklar gösteren penisilin türevleri elde edilir (Dural, 2008).

Penisilinler, bakteri ve mantar enfeksiyonlarını önlemek için veterinerlik ve tıbbi ilaç uygulamalarında yaygın olarak kullanılmaktadırlar (Riediker vd., 2004; Becker vd., 2004). Penisilinlerin olumlu etkilerine rağmen, tüketiminden sonra gida veya sulu ortamlarda bulunması ciddi sağlık tehdidi oluşturmaktadır. Ayrıca hayvan yemindeki penisilin kalıntılarının varlığı, insanların et ve süt ürünlerini tüketmesi ile ağır alerjik tepki gibi halk sağlı̆̆ üzerinde olumsuz etkiler yaratabilmektedir (Fagerquist ve Lightfield, 2003). Bunun yanında farmokinetik çalışmalarda ilacı ve herhangi bir bozunma ürününün ayırt edilmesi gerekliliği ve alerjik reaksiyonların sıklıkla penisilin grubu bileşiklerden kaynaklanması penisilinlerin analizini önemli bir hale getirmiştir (Joshi, 2002). Penisilinlerin tayini için kullanılan mikrobiyal inhibisyon ve immünolojik testler gibi biyoanalitik yöntemler bulunmaktadır (Babington vd., 2012; Song vd., 2015). Fakat yüksek performansı, karışımları ön işleme tabi tutmadan ayırma ve tayin edebilme gücü, hızı ve oldukça iyi duyarlılı̆̆a sahip olması gibi avantajları sebebiyle bu antibiyotiklerin tayininde yüksek performans sıvı kromatografi (HPLC) yöntemi tercih edilmektedir (Camara vd., 2013).

Misellar sıvı kromatografisi (MSK), hareketli fazın kritik misel konsantrasyonunun üzerinde yüzey aktif madde içerdiği bir sıvı kromatografisi yöntemidir (El-Shaheny, vd., 2015). MSK'de hareketli faza bir yüzey aktif madde ekleyerek hareketli fazın ve kolonun polaritesini değiştirmek ve böylece organik bir çözücü kullanmadan kromatografik ayırımı gerçekleştirmek mümkündür. Kullanılan yüzey aktif maddenin konsantrasyonunun, kritik misel konsantrasyonu olarak adlandırılan ve her yüzey aktif madde için farklı olan belirli bir konsantrasyon değerinin üzerinde olması gerekmektedir (Berthod ve Garcia-Alvarez-Coque, 2000). Bir yüzey aktif maddenin sulu çözeltideki konsantrasyonu kritik misel konsantrasyonunun üzerine çıkarıldığında; bu madde sulu çözelti içinde miseller halinde toplanmaya başlamaktadır. Çözelti, su ve misel yapı olmak üzere iki kısımdan oluşmuş gibidir. Kolon sabit fazı bu sistemin üçüncü unsurunu oluşturmakta ve hareketli fazda bulunan analitler, su - miseller yapı - kolon sabit fazı olmak üzere üçlü bir sistem içinde dağılım göstermektedir. Böylece polar ve apolar karakterli pek çok bileşenin kromatografik ayırımının sağlanabileceği belirtilmektedir (Ruiz-Angel vd., 2002). Yüzey aktif maddeler kolon polaritesini değiştirerek iyonik ve iyonik olmayan analitlerin eşzamanlı analizini de mümkün kılmaktadır. HPLC çalışmalarında en yaygın olarak kullanılan yüzey aktif madde sodyum dodesil sülfattır (SDS). Uygun maliyetli olması, düşük basınçlı bileşiklere uygulanabilirliği, mobil fazda yüzey aktif madde kullanımı nedeniyle biyolojik olarak parçalanabilir (yani çevre dostu) özelliği, biyolojik numunelerin doğrudan enjeksiyon kabiliyetine sahip olması gibi çok sayıda avantajlarının olması MSK'nin kullanımını arttırmaktadır (Ramezani vd., 2018).

Bu çalışmada, metisilin, penisilin V, amoksasilin ve ampisilinin ayrımı ve Penisilin V'nin kantitatif analizi için hızlı, yüksek seçicilik ve duyarlılıkta MSK yöntemi geliştirilmiştir. Geliştirilen yöntemin geçerliliğinin kanıtlanması amacıyla doğrusallık, duyarlık, seçicilik, kesinlik, geri kazanım, tespit ve tayin sınırları gibi validasyon parametreleri incelenmiş ve istatiksel değerlendirmeler yapılmıştır. Geliştirilen ve valide edilen MSK yöntemi penisilin V'nin ilaç ve biyolojik sıvı numunelerindeki kantitatif analizine uygulanmıştır. 


\section{Materyal ve Metot}

\subsection{Kullanılan Kimyasal Maddeler}

Deneysel çalışmalarda kullanılan tüm kimyasallar analitik saflıktadır. 1-bütanol (\%99,9), o-fosforik asit (\%85), sodyum dodesil sülfat (\%85), urasil ( $>99$ ) Merck (Darmstadt, Germany) firmasından; metisilin, penisilin V, amoksasilin, ampisilin Sigma-Aldrich (St. Louis, MO, USA) firmasından temin edilmiştir. Pen-Os 1000 film (Sandoz İlaç Sanayi ve Ticaret A.Ş.) ve Cliacil 1.2. Mega film tabletleri (Bilim İlaç Sanayi ve Ticaret A.Ş.) yerel bir eczaneden satın alınmıştır.

\subsection{Kullanılan Cihazlar}

Penisilin grubu antibiyotiklerin sıvı kromatografik davranışlarının incelenmesinde Shimadzu (Shimadzu Technologies, Kyoto, Japan) marka yüksek performans sıvı kromatografi cihazı (HPLC) kullanılmıştır. HPLC sisteminde, pompa (LC-10AD VP), autosampler (SIL-20A), kolon firını (CTO-10AS), gaz giderme ünitesi (DGU-20A) ve diode array dedektör (SPD-M20A) bulunmaktadır. Mobil fazın pH ölçümleri pH/iyon metre (Mettler Toledo S220, Schwerzenbach, Switzerland) ve Mettler Toledo InLab $416 \mathrm{Ag} / \mathrm{AgCl}$ kombine elektrot ile gerçekleştirilmiştir. Çözeltilerin hazırlanmasında ultrasonik banyo (Elmasonic S15) kullanılmıştır

\subsection{Kromatografik Koşullar}

Seçilen bileşiklerin kromatografik davranışlarının incelenmesinde mobil faz olarak \% 5(v/v) 1-bütanol-su ortamında $0,05 \mathrm{M}$ sodyum dodesil sülfat içeren $0,01 \mathrm{M}$ fosfat $(\mathrm{pH} \mathrm{3,5)}$ tamponu kullanılmıştır. İzokratik elüsyon X-Terra RP18 (250 mm x 4,6 mm I.D., $5 \mu \mathrm{m})$ kolununda gerçekleştirilmiştir. Çalışma $1,3 \mathrm{~mL} / \mathrm{dk}$ akış hızı, $20 \mu \mathrm{L}$ enjeksiyon hacmi, $30{ }^{\circ} \mathrm{C}$ kolon sıcaklığı ve $200 \mathrm{~nm}$ dalga boyunda yürütülmüştür.

\section{4. Çözeltilerin Hazırlanması}

Standartların (metisilin, penisilin V, amoksasilin, ampisilin) stok çözeltileri $100 \mathrm{mg} / \mathrm{L}$ derişimde hazırlanmıştır. Bu amaçla her bir standart 0,5 mg tartılıp üzerine $5 \mathrm{~mL} 0,05 \mathrm{M}$ SDS içeren $0,01 \mathrm{M}$ fosfat $(\mathrm{pH} 3,5)$ çözeltisi ilave edilmiş, $5 \mathrm{dk}$ ultrasonik banyoda bekletilmiş ve $0,45 \mu$ m'lik filtreden süzülmüştür. Enjeksiyon yapılacak derişimlerde mobil faz ile seyreltmeler yapılmıştır. Çalışan bileşiklerin kimyasal yapıları Şekil 1'de verilmiştir.

Çalışılan koşullarda kapasite faktörlerinin belirlenmesi için kullanılan urasil çözeltisi, derişimi $10 \mathrm{mg} / \mathrm{L}$ olacak şekilde $0,05 \mathrm{M}$ SDS içeren 0,01 M fosfat $(\mathrm{pH} 3,5)$ çözeltisinde hazırlanmıştır. Urasilin hazırlanan bu çözeltisinden $20 \mu \mathrm{L}$ enjekte edilerek kolonda tutunmayan türe özgü to alıkonma zamanı belirlenmiştir.

\subsection{Numunelerin Hazırlanması}

Farmasötik numunelerde miktar tayini yapabilmek amacıyla 10 tablet ezilmiş ve 1 tablete eşdeğer miktardaki tablet tozu, $25 \mathrm{~mL}$ 'lik balon jojeye alınmıştır. Üzerine ultra saf su eklenerek ultrasonik banyoda 15 dakika çözünmesi için bekletilmiştir ve hazırlanan çözelti $0,45 \mu \mathrm{m}$ 'lik fitreden süzülmüştür. Penisilin V'nin kalibrasyon aralığındaki derişimde olacak şekilde bu süzüntüden mobil faz ile seyreltme yapılmıştır. Her iki tablet numunesine (Pen-Os 1000 film tablet ve Cliacil tablet) aynı işlem uygulanmıştır.

İdrar numunesi Penisilin V içeren ilacı kullanmayan sağlıklı bireylerden alınmıştır. Belirli miktar idrar 2000 devir/dakika hızla 15 dakika santrifüjlenerek proteinlerin çökmesi sağlanmış ve süpernatant kısım alınarak 0,45 $\mu$ m'lik filtreden geçirilmiştir. Analizlerde 1:50 oranında idrar içeren çözeltiler hazırlanmıştır. Penisilin V standart çözeltisinden 7,5 mg/L olacak şekilde idrar numunesine katkı yapılmıştır.

\section{Araştırma Sonuçları ve Tartışma}

Penisilin grubu antibiyotiklerden olan; metisilin, penisilin V, amoksasilin ve ampisilinin ayrımı ve farmasötik ve insan idrar numunelerinde Penisilin V'nin kantitatif analizi X-Terra RP18 (250 mm x 4,6 mm I.D., $5 \mu \mathrm{m})$ kolunu ve \% 5(v/v) 1-bütanol-su ortamında 0,05 M SDS içeren 0,01 M fosfat (pH 3,5) tamponu kullanılarak gerçekleştirilmiştir. Belirlenen koşullar için veriler, sistem uygunluk testleri bakımından değerlendirilmiştir. Sistem Uygunluk Testleri (SUT), Food Drug Administration (FDA) ve United States Pharmacopeia (USP) tarafindan önerilen sıvı kromatografisi ve diğer ayırma tekniklerinde yöntem geliştirmenin bir parçasını oluşturan testlerdir. Belirli derişimlerde hazırlanan çözeltilerin sisteme enjeksiyonundan sonra cihazdan alınan verilerin kromatografik parametreleri hesaplanmıştır (Tablo 1). Her bir kapasite faktörünün hesaplanmasında kolonda tutunmayan türe özgü t $t_{0}$ alıkonma zamanının belirlenmesi için urasil kullanılmıştır ve $t_{0}$ değeri 2,714 dakikadır. Sistem uygunluk testlerinin gerçekleştirildiği koşula ait kromatogram Şekil 2' de verilmiştir.

Tablo 1'de görüldüğü gibi kapasite faktörünün (k) 1-10 arasında, seçicilik katsayısı ( $\alpha$ ) değerinin 1,15'in üzerinde ve ayırma gücü $\left(\mathrm{R}_{\mathrm{s}}\right)$ değerinin 1,5'in üzerinde olması yöntemin sistem uygunluk parametreleri açısından uygunluğunu göstermektedir. 
<smiles>COc1cccc(OC)c1C(=O)N[C@@H]1C(=O)N2[C@@H](C(=O)O)C(C)(C)S[C@H]12</smiles>

Metisilin<smiles>CC1(C)S[C@@H]2[C@H](NC(=O)[C@@H](N)c3ccc(O)cc3)C(=O)N2[C@H]1C(=O)O</smiles>

Amoksasilin<smiles>CC1(C)S[C@@H]2[C@H](NC(=O)COc3ccccc3)C(=O)N2[C@H]1C(=O)O</smiles>

Penisilin V<smiles>CC1(C)S[C@@H]2[C@H](NC(=O)[C@@H](N)c3ccccc3)C(=O)N2[C@H]1C(=O)O</smiles>

Ampisilin

Şekil 1. Çalışılan bileşiklerin kimyasal yapıları

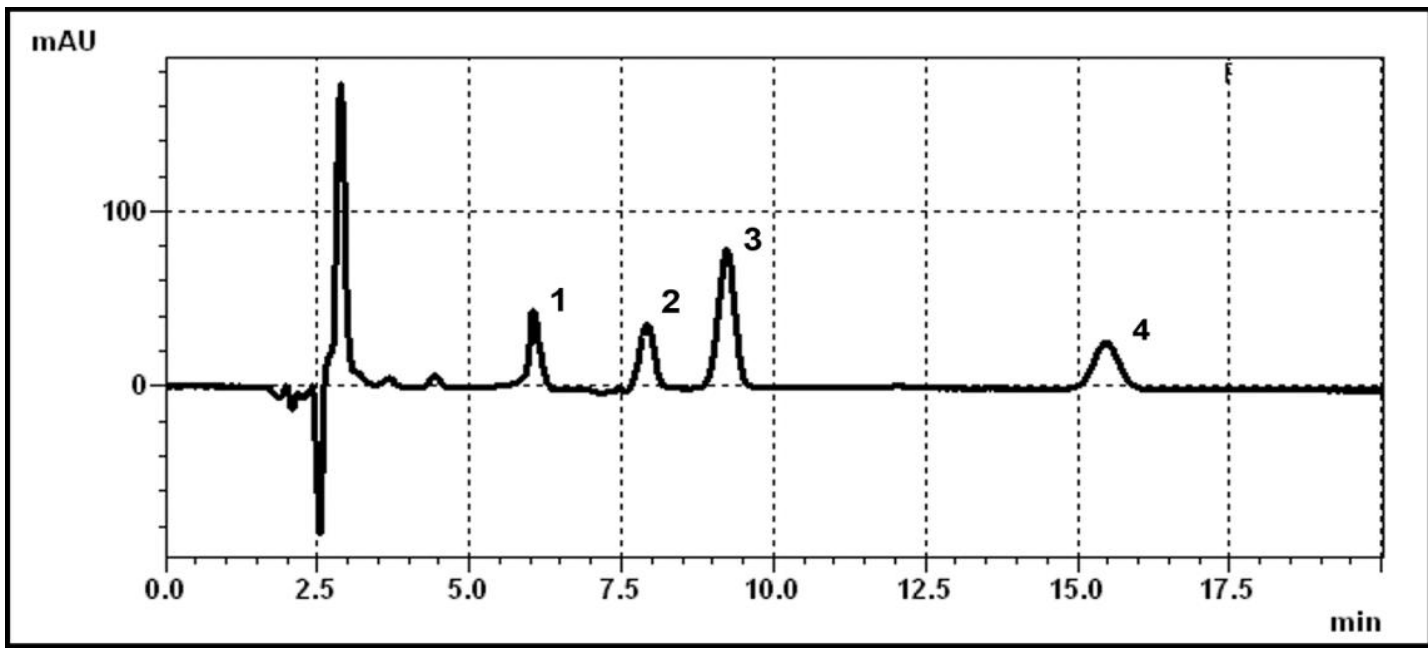

Şekil 2. Standart karışım (her biri $15 \mathrm{mg} / \mathrm{L}$ ) kromatogramı: 1) metisilin, 2) penisilin V, 3) amoksasilin 4) ampisilin (\%5(v/v) 1bütanol-su ortamında $0,05 \mathrm{M}$ SDS içeren $0,01 \mathrm{M}$ fosfat (pH 3,5) tamponu, akış hızı 1,3 mL/dk, 300)

Tablo 1. Sistem uygunluk parametreleri

\begin{tabular}{c|ccccc}
\hline Parametreler & Önerilen Değer & Metisilin & Penisilin V & Amoksasilin & Ampisilin \\
\hline Alıkonma zamanı (dk) & & 6,040 & 7,908 & 9,215 & 15,471 \\
Kapasite faktörü (k) & $1-10$ & 1,225 & 1,913 & 2,395 & 4,700 \\
Seçicilik ( $\alpha)$ & $\geq 1,15$ & - & 1,561 & 1,251 & 2,305 \\
Kuyruklanma faktörü (TF) & $\leq 2$ & 1,025 & 1,057 & 0,974 & 1,029 \\
Tabaka sayısı (N) & $>2000$ & 5680 & 4870 & 5166 & 6119 \\
Ayırma gücü (Rs) & $\geq 1,5$ & - & 6,919 & 2,533 & 9,121 \\
\% RSD (Alıkonma zamanı) & $\leq 1$ & 0,066 & 0,184 & 0,186 & 0,141 \\
\hline
\end{tabular}

Penisilin V'nin analizi enjeksiyon hacminden gelen hataları ortadan kaldırmak iç standart tekniği kullanılarak yapılmıştır. Kalibrasyon fonksiyonu hazırlanırken iç standardın derişimi sabit tutulmaktadır. Kalibrasyon fonksiyonu y ekseninde analitin alanının e-ISSN: $2148-2683$ 
iç standardın alanına oranı; $x$ ekseninde analitin derişimi ile oluşturulur. Penisilin V’nin kantitatif tayini için seçicilik ve ayırma gücü göz önüne alınarak iç standart (I.S) olarak penisilin grubundan ampisilin seçilmiştir. Şekil 3'de Penisilin V ve ampisilinin (I.S) standart karışım kromatogramı verilmiştir.

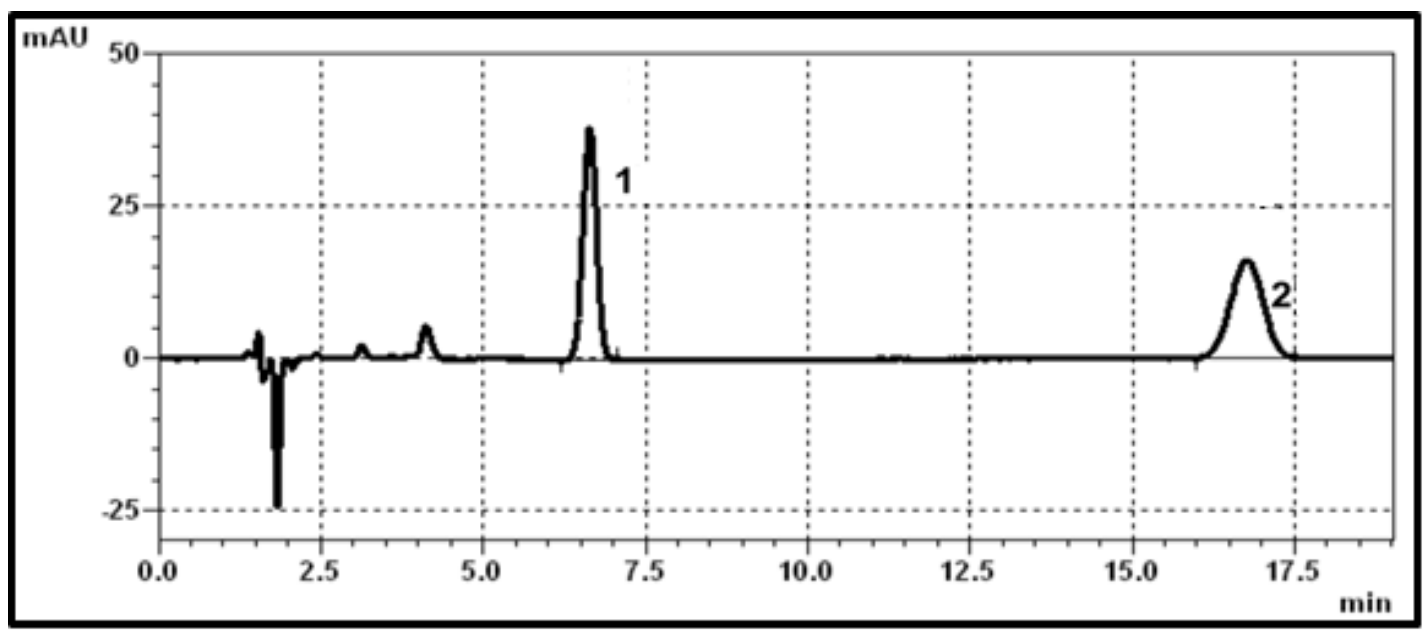

Şekil 3. Standart karışım kromatogramı; 1) penisilin V (17 mg/L) 2) ampisilin (I.S) (10 mg/L) (\%5(v/v) 1-bütanol-su ortamında 0,05 M SDS içeren 0,01 M fosfat (pH 3,5) tamponu, akış hızı 1,3 mL/dk, $\left.30^{\circ} \mathrm{C}\right)$

Penisilin V'nin MSK yöntemiyle kalibrasyon fonksiyonunun doğrusal aralı̆̆ınının belirlenmesinde $2 \mathrm{mg} / \mathrm{L}$ ile $20 \mathrm{mg} / \mathrm{L}$ arasında farklı derişimlerde çözeltiler hazırlanmıştır. Ampisilin (I.S) $10 \mathrm{mg} / \mathrm{mL}$ sabit derişimde enjekte edilmiştir. Kalibrasyon fonksiyonu, her bir derişim değeri için penisilin $\mathrm{V}$ pik alanının ampisilin pik alanına oranının, penisilin $\mathrm{V}$ derişimine karşı işaretlenmesiyle elde edilmiştir (Şekil 4). Penisilin V için $2 \mathrm{mg} / \mathrm{L}$ ile $20 \mathrm{mg} / \mathrm{L}$ konsantrasyon aralığında beş noktalı kalibrasyon eğrisi oluşturulmuştur. Penisilin V analizi için doğrusal kalibrasyon fonksiyonu, teşhis sınırı (LOD) ve tayin alt sınırı (LOQ) değerleri Tablo 2'de verilmiştir. Elde edilen doğrusal kalibrasyon fonksiyonun korelasyon katsayısının 1'e çok yakın olduğu gözlenmiştir. Bu kalibrasyon eğrisinden 2 farklı konsantrasyon seçilip (5 mg/L ve $10 \mathrm{mg} / \mathrm{L})$ gün içi ve günler arası üçer enjeksiyon yapılmış ve yöntemin kesinliği belirlenmiştir (Tablo 3).

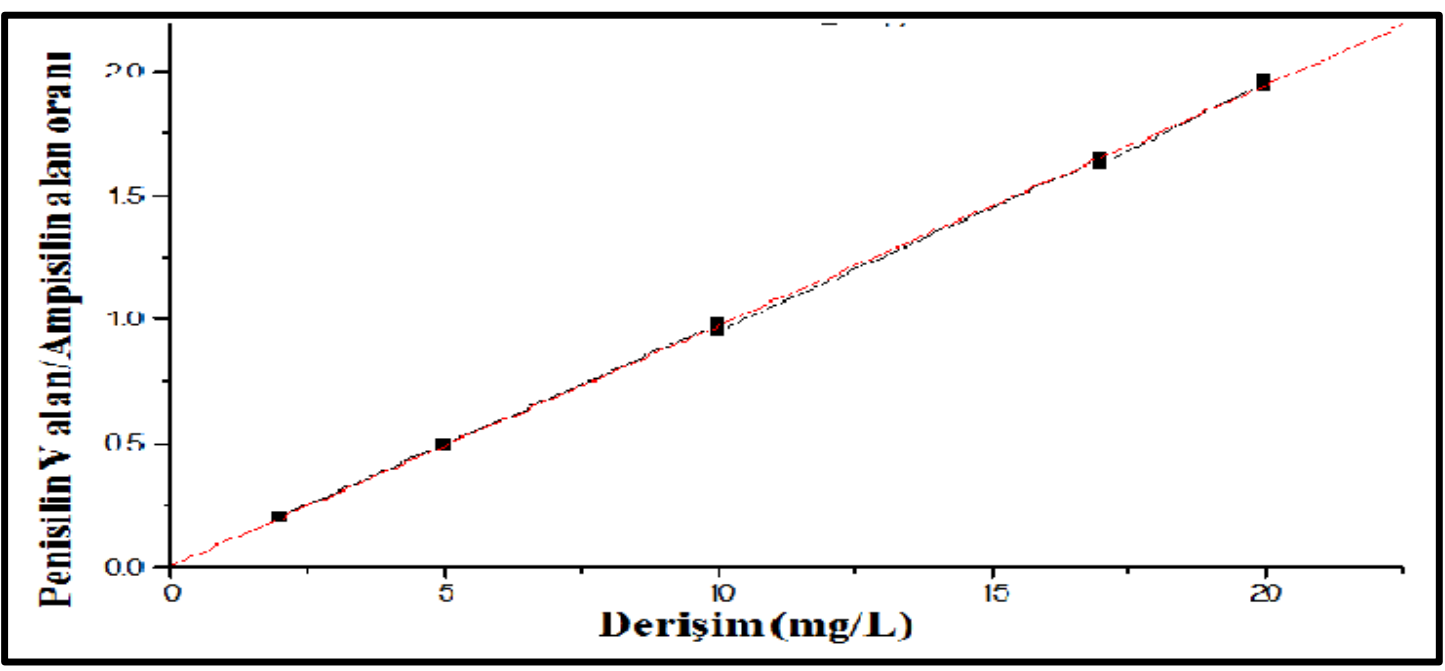

Şekil 4. Penisilin V’nin analizine ait doğrusal grafik 
Tablo 2. Penisilin V'nin analizine ait doğrusal kalibrasyon fonksiyon verileri $(n=5)$

\begin{tabular}{cc}
\hline & Penisilin V \\
\hline Kalibrasyon aralığı (mg/L) & $2-20$ \\
Regresyon denklemi & $\mathrm{y}=0,09683 \mathrm{x}+0,00583$ \\
Ĕgimin standart hatası & 0,00053 \\
Kesimin standart hatası & 0,00658 \\
Korelasyon katsayısı (r) & 0,9998 \\
LOD (mg/L) & 0,203 \\
LOQ (mg/L) & 0,679 \\
\hline
\end{tabular}

Tablo 3. Penisilin V’nin analiz yöntemine ait gün içi ve günler arası kesinlik analiz bulguları

\section{Gün içi Günler arası}

\begin{tabular}{cccccc} 
Bileşik & \begin{tabular}{c} 
Teorik derişim \\
\cline { 3 - 5 }
\end{tabular} & $\begin{array}{c}\text { Ortalama derişim } \\
(\mathbf{m g} / \mathbf{L})\end{array}$ & $\begin{array}{c}\text { RSD } \\
(\mathbf{m g} / \mathbf{L}) \pm \mathbf{S D}\end{array}$ & $\begin{array}{c}\text { Ortalama derişim } \\
\mathbf{( m g} / \mathbf{L}) \pm \mathbf{S D}\end{array}$ & $\begin{array}{c}\text { RSD } \\
\mathbf{\%}\end{array}$ \\
\hline Penisilin V & 5 & $5,03 \pm 0,02$ & 0,48 & $4,75 \pm 0,06$ & 1,38 \\
& 10 & $10,05 \pm 0,04$ & 0,37 & $10,12 \pm 0,08$ & 0,82 \\
\hline
\end{tabular}

Penisilin V tayini için geliştirilen yöntem piyasa ilaç preparatlarına (Pen-Os ve Cliacil) uygulanmıştır. Hazırlanan tablet çözeltilerinden penisilin V derişim kalibrasyonuna uygun şekilde seyreltme yapılmıştır ve $10 \mathrm{mg} / \mathrm{L}$ derişimde iç standart ile katkılandırılmıştır. Yapılan analiz sonuçlarında okunan pik alan değerleri, ilgili kalibrasyon denkleminde değerlendirilerek tabletlerin içerdiği penisilin V miktarları hesaplanmıştır. Hesaplamalar sonucunda tabletlerde bulunan penisilin V miktarı Tablo 4'de verilmiştir. Pen-Os ve Cliacil tabletlerde analit miktarının belirlendiği koşula ait kromatogramlar Şekil 5'de verilmiştir.
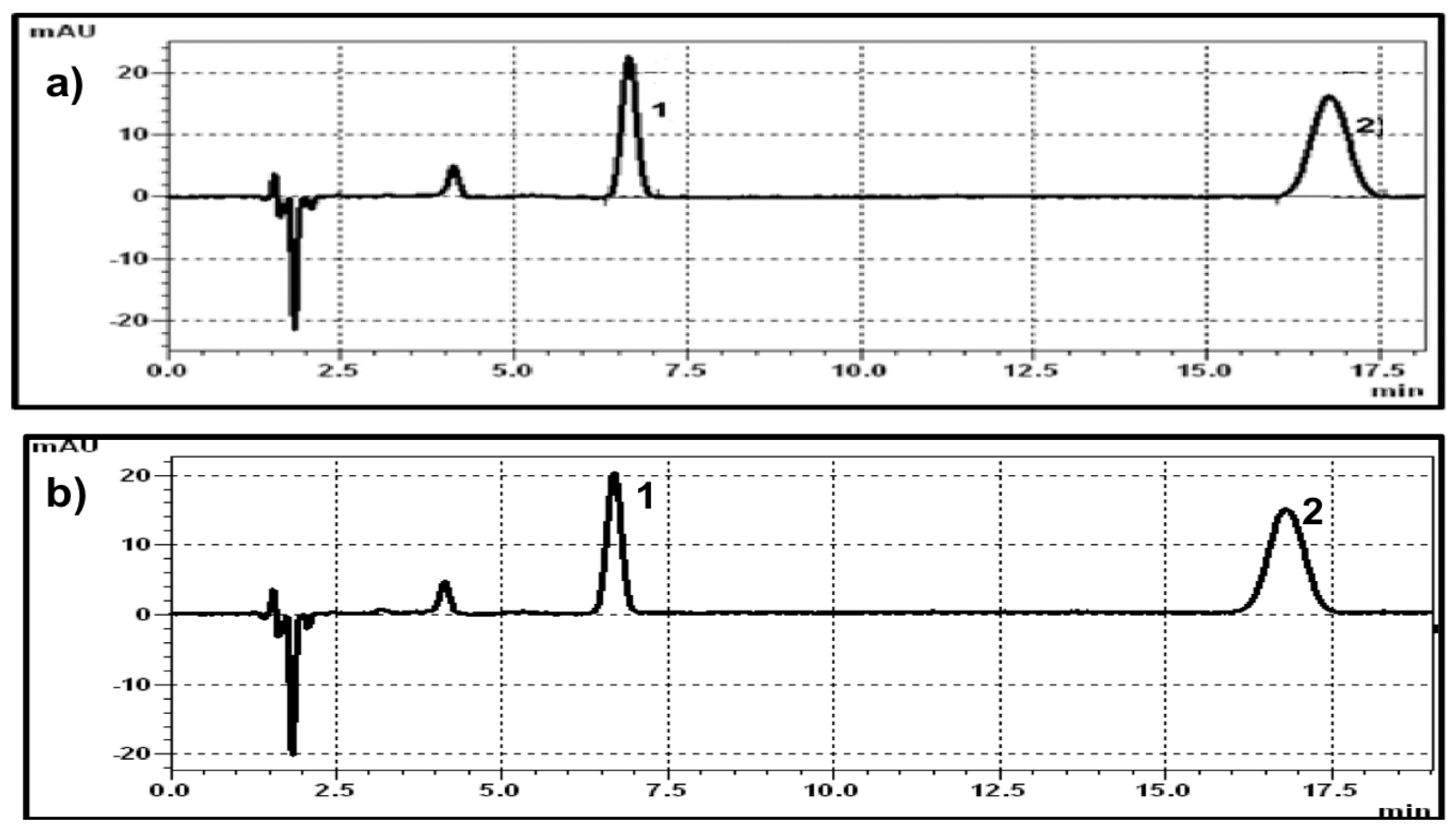

Şekil 5. Pen-Os ve Cliacil tabletlerin analiz yöntemine ait $200 \mathrm{~nm}$ 'de alınan kromatogramları; 1) penisilin V (7,5 mg/L) 2) ampisilin

(I.S) $(10 \mathrm{mg} / \mathrm{L})(\% 5(\mathrm{v} / \mathrm{v})$ 1-bütanol-su ortamında 0,05 M SDS içeren 0,01 M fosfat (pH 3,5) tamponu, akış hızı 1,3 mL/dk, 30 $\mathrm{C})$ 
Tablo 4. Penisilin Viçeren Pen-Os ve Cliacil tabletlerinin analizine ait bulgular

\begin{tabular}{cccc}
\hline Numune & $\begin{array}{c}\text { Teorik derişim } \\
(\mathbf{m g} / \mathbf{L})\end{array}$ & $\begin{array}{c}\text { Ortalama derişim } \\
(\mathbf{m g} / \mathbf{L}) \pm \mathbf{S D}\end{array}$ & $\begin{array}{c}\text { RSD } \\
\mathbf{\%}\end{array}$ \\
\hline Pen-Os 1000 tablet $(\mathbf{m g} / \mathbf{L})$ & 7,50 & $6,04 \pm 0,06$ & 1,01 \\
Cliacil tablet $(\mathbf{m g} / \mathbf{L})$ & 7,50 & $5,94 \pm 0,14$ & 2,49 \\
\hline
\end{tabular}

Geliştirilen yöntem idrar numunesine de uygulanmıştır. Sağlıklı bir insanda dışarıdan vücuda alınmadıkça Penisilin V bulunmamaktadır. Kromatogramın başındaki proteinlerden kaynaklanan piklerin ve endojen bileşiklerin çeşitli alıkonma zamanlarında gözlenen piklerin şiddetinin azaltılması amacıyla idrar numunesi enjeksiyondan önce mobil faz ile 1:50 oranında seyreltilmiştir. Penisilin V katkılandırılmış idrar numunesinde kalibrasyon grafiği oluşturulmuş ve lineer aralık 2-20 mg/L olarak belirlenmiştir. Doğru denklemi $\mathrm{y}=0,12505 \mathrm{x}-0,02176$ ve korelasyon katsayısı 0,9990 olarak elde edilmiştir. Penisilin V standart çözeltisinden idrar numunesine 7,5 mg/L olacak şekilde katkı yapılmıştır. İdrar ve katkılandırılmış idrar numunesinin analizi sonucu elde edilmiş kromatogramlar Şekil 6'da verilmiştir. Analiz sonucunda okunan pik alan değerlerinin oranı ilgili kalibrasyon denkleminde yerine konularak idrar numunesinin içerdiği penisilin V miktarı hesaplanmıştır. Geliştirilen yöntemle yapılan analiz sonucu Tablo 5'de verilmiştir. Penisilin V katkılanmış idrar numunesinde geri kazanım değeri \%100’e yakın bulunmuştur.
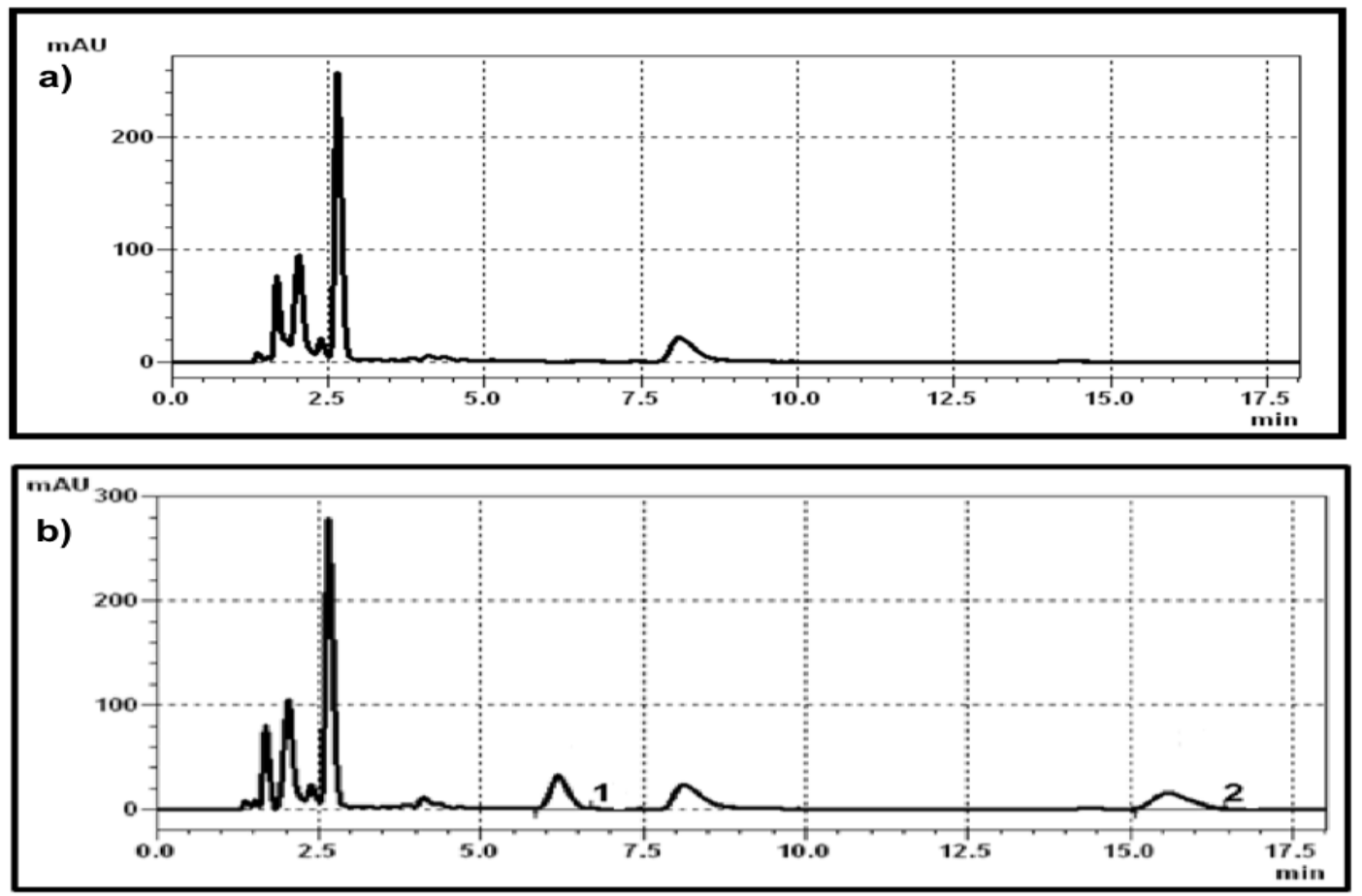

Şekil 6. a) İdrar numunesi b) Penisilin V (7,5 mg/L) katkılanmış idrar numunesi kromatogramları; 1) penisilin V 2) ampisilin (I.S) (\%5(v/v) 1-bütanol-su ortamında 0,05 M SDS içeren 0,01 M fosfat ( $\mathrm{pH} 3,5)$ tamponu, akış hızı 1,3 mL/dk, 30 ${ }^{\circ} \mathrm{C}$ )

Tablo 5. Penisilin V katkısı yapllan idrar numunesi analizine ait bulgular

\begin{tabular}{ccccc}
\hline Numune & $\begin{array}{c}\text { Teorik derişim } \\
(\mathbf{m g} / \mathbf{L})\end{array}$ & $\begin{array}{c}\text { Ortalama derişim } \\
(\mathbf{m g} / \mathbf{L}) \pm \mathbf{S D}\end{array}$ & $\begin{array}{c}\text { RSD } \\
\mathbf{\%}\end{array}$ & $\begin{array}{c}\text { Geri Kazanım } \\
\mathbf{\%}\end{array}$ \\
\hline İdrar & 7,50 & $7,51 \pm 0,05$ & 0,65 & 100,13 \\
\hline
\end{tabular}




\section{Sonuç}

Bu çalışmada penisilin grubundan 4 bileşiğin (metisilin, penisilin V, amoksasilin ve ampisilin) ayrımı ve Penisilin V'nin kantitatif tayini için basit, kesin, doğru ve tekrarlanabilir MSK yöntemi geliştirilmiştir. Belirlenen koşul için veriler, sistem uygunluk testleri bakımından değerlendirilmiştir. Kantitatif tayin için gerekli olan; seçicilik katsayı değerinin 1,15'den ve ayırma gücü değerinin 1,5'den büyük olduğu belirlenmiştir. Geliştirilen yöntemin elde edilen parametreler 1şı̆ğnda uygulanabilir olduğu bulunmuştur. Yöntemin geçerliliğinin kanıtlanması amacıyla lineer aralık, duyarlık, kesinlik, geri kazanım parametreleri incelenmiş ve istatiksel değerlendirmeler yapılmıştır. Penisilin V için kalibrasyon grafiği $2 \mathrm{mg} / \mathrm{L}$ ile $20 \mathrm{mg} / \mathrm{L}$ arasında doğrusaldır ve korelasyon katsayısı (r) ise 0,9998 olarak belirlenmiştir. LOD $0,203 \mathrm{mg} / \mathrm{L}$; LOQ ise $0,679 \mathrm{mg} / \mathrm{L}$ olarak hesaplanmıştır. Bileşiklerin tayini için kesinlik çalışmaları $5 \mathrm{mg} / \mathrm{L}$ ve $10 \mathrm{mg} / \mathrm{L}$ derişimlerinde gerçekleştirilmiştir. Gün-içi ve günler-arası kesinlik değerlerinin \% RSD’si 5 mg/L için sırasıyla 0,48 ve $1,38^{\prime}$ dir. $10 \mathrm{mg} / \mathrm{L}$ için günler içi ve günler arası \% RSD değerleri ise sırasıyla 0,37 ve 0,82 olarak hesaplanmıştır. Bu veriler 1şı̆̆ında penisilin V'nin farmasötik ve insan idrar numunelerindeki kantitatif tayini, iç standart yöntemiyle gerçekleştirilmiştir. Geliştirilen yöntemde numuneler herhangi bir ön-işlem adımı olmaksızın doğrudan enjekte edilmiştir. Elde edilen sonuçlar, bu yöntemin ilaç ve biyolojik uygulamalarda penisilin V'nin rutin analizi için kullanılabileceğini göstermektedir.

\section{Kaynakça}

Babington, R., Matas, S., Marco, M.P., Galve, R. (2012), Current bioanalytical methods for detection of penicillins, Analytical and Bioanalytical Chemistry, 403, 1549-1566.

Becker, M., Zittlau, E., Petz, M. (2004), Esidue analysis of 15 penicillins and cephalosporins in bovine muscle, kidney and milk by liquid chromatography-tandem mass spectrometry, Analytical Chemistry Acta, 520, 19-32.

Berthod, A., Garcia-Alvarez-Coque, M.C. (2000), Micellar Liquid Chromatography, 622 p. Marcel Dekker Inc. Newyork.

Cámara, M., Gallego-Picó, A., Garcimuño, R.M., Fernández-Hernando, P., Durand-Alegría, J.S., Sánchez, P.J. (2013), An HPLC-DAD method for the simultaneous determination of nine $\beta$-lactam antibiotics in ewe milk, Food Chemistry, 141, 829-834.

Dural, E.A.Ö., (2012), Farmakoloji, İstanbul: Nobel Tıp Kitapevleri.

El-Shaheny, R.N., El-Maghrabey, M.H., Belal, F.F. (2015), Micellar liquid chromatography from green analysis perspective, Open Chemistry, 13, 877-892.

Evaggelopoulou, E. N., Samanidou, V. F., (2013), Development and validation of an HPLC method for the determination of six penicillin and three amphenicol antibiotics in gilthead seabream (Sparus Aurata) tissue according to the European Union Decision 2002/657/EC, Food Chemistry, 136, 1322-1329.

Fagerquist, C.K., Lightfield, A.R. (2003), Confirmatory analysis of $\beta$-lactam antibiotics in kidney tissue by liquid chromatography/electrospray ionization selective reaction monitoring ion trap tandem mass spectrometry, Rapid Communications in Mass Spectrometry, 17, 660-671.

Joshi, S., (2002), HPLC separation of antibiotics present in formulated and unformulated samples, Journal of Pharmaceutical and Biomedical Analysis, 28, 795-809

Pryde, A., Gilbert, M.T. (1999), Applications of High Performance Liquid Chromatography, Mishawaka: Better Word Books.

Ramezani, A.M., Absalan, G., Ahmadi, R. (2018), Green-modified micellar liquid chromatography for isocratic isolation of some cardiovascular drugs with different polarities through experimental design approach, Analytical Chemistry Acta, 1010, 76-85.

Riediker, S., Rytz, A., Stadler, S.H. (2004), Cold-temperature stability of five $\beta$-lactam antibiotics in bovine milk and milk extracts prepared for liquid chromatography-electrospray ion- ization tandem mass spectrometry analysis, Journal of Chromatography A, 1054, 359-363.

Ruiz-Angel, M.J., Caballero, R.D., Simo-Alfonso, E.F., Garcia-Alvarez-Coque, M.C. (2002), Micellar liquid chromatography: suitable technique for screening analysis, Journal of Chromatography A 947(1): 31-45.

Samanidou, V. F., Evaggelopoulou, E. N. (2007), Analytical strategies to determine antibiotic residues in fish, Journal of Separation Science, 30, 2549-2569.

Samanidou, V. F., Evaggelopoulou, E. N., Papadoyannis, I. N. (2006), Chromatographic analysis of penicillins in pharmaceutical formulations and biological fluids, Journal of Separation Science, 29, 1879-1908.

Schugerl, K. (2001), Progress in Monitoring, Modeling and Control of Bioprocesses During the Last 20 Years, Journal of Biotechnology, 85, 149-173.

Song, E., Yu, M., Wang, Y., Hu, W., Cheng, D., Swihart, M.T., Song, Y. (2015), Multi-color quantum dot-based fluorescence immunoassay array for simultaneous visual detection of multiple antibiotic residues in milk, Biosensors and Bioelectronics, 72, 320-325.

Tong, L., Wang, Y.X., Hermo, M.P., Barrón, D., Barbosa, J. (2014), Simultaneous determination and toxicological assessment of penicillins in different water matrices, Ecotoxicology 23, 2005-20. 